ENTREPRENEURSHIP AND SUSTAINABILITY ISSUES

ISSN 2345-0282 (online) http://jssidoi.org/jesi/ 2021 Volume 9 Number 1 (September)

http://doi.org/10.9770/jesi.2021.9.1(40)
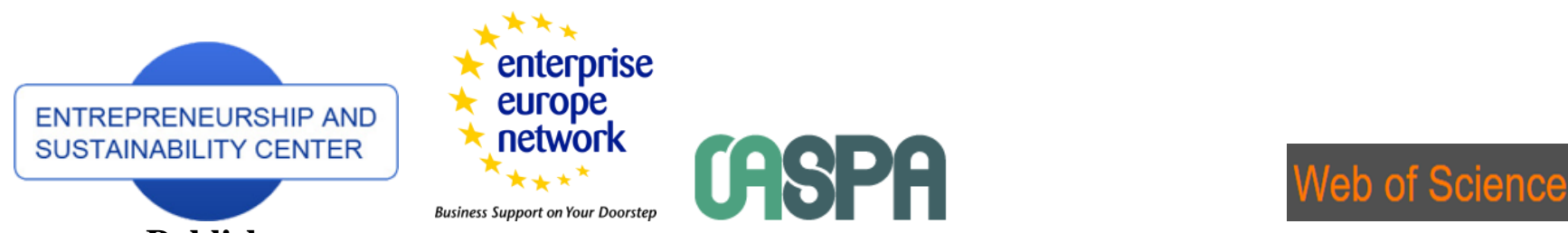

http://jssidoi.org/esc/home

Business Support on Your Doorstep PA

\title{
CROSSING THE VALLEY OF DEATH: LESSONS FOR YOUNG ENTREPRENEURS
}

\author{
Mohammed Emad Al-Shaikh ${ }^{1}$, Kamran Siddiqui ${ }^{2 *}$ \\ ${ }^{12}$ College of Business Administration, Imam Abdulrahman Bin Faisal University, 2835 King Faisal Road - Dammam, \\ Saudi Arabia \\ E-mails: ${ }^{1}$ mealshaikh@iau.edu.sa, ${ }^{2 *}$ kasiddiqui@iau.edu.sa (Corresponding author)
}

Received 18 July 2021; accepted 3 September 2021; published 30 September 2021

\begin{abstract}
Valley of Death $(\mathrm{VoD})$ is a metaphor often used to describe the situation in which many new startups fail to survive. This paper aims to share the experiences of developing guidelines for young entrepreneurs to successfully cross the Valley of death. The ideal target audience for this paper includes young entrepreneurs eager to launch their startups and preferably attending business incubation or acceleration programs. This research hypothesized to make a conceptual model crossing the Valley of death using the entrepreneurial ecosystem. The entrepreneurship ecosystem consists of six higher-order domains, including enabling government policies and leadership, financial capital, culture, support services, human capital, and markets. From earlier studies, entrepreneurial actions to cross the Valley of death were extracted. Entrepreneurship experts, including business incubation center managers, mentors, entrepreneurship faculty from business schools, validated these entrepreneurial actions. Analyses show four domains replicated in the study, enabling government policies and leadership, financial capital, support services, and markets. Furthermore, culture was partially replicated while the experts did not validate human capital. Finally, it presents entrepreneurial actions used to cross the Valley of death by new startups. These entrepreneurial actions are mapped on the entrepreneurial ecosystem. Findings include an emphasis on the understanding of ten issues including, entrepreneurial ecosystem, government rules, procedures, and incentives (like tax benefits, grants) for similar startups, intellectual property rights for similar projects, the role of leadership in startup performance, financial capital for the startup, risks and decision-making choices, regional entrepreneurial culture, support services for similar startups, markets, customers \& competitors, the commercial value of the research project/product. Findings also show how to perform these actions and the appropriate timings of these entrepreneurial actions.
\end{abstract}

Keywords: Valley of Death; entrepreneurship; lessons for entrepreneurs

Reference to this paper should be made as follows: Al-Shaikh, M.E., Siddiqui, K.A. (2021). Crossing the Valley of Death: lessons for young entrepreneurs. Entrepreneurship and Sustainability Issues, 9(1), 644-662. http://doi.org/10.9770/jesi.2021.9.1(40)

JEL Classifications: L26 


\section{Introduction}

One critically important concept for new startups is the concept of the Valley of death; a metaphor often used to describe the gap between innovations and their commercialization in the marketplace (Markham, 2002, Merrifield, 1995). The left side of the Valley shows entrepreneurs with ideas, scientists, innovation teams, and university resources necessary for startups. This is the technology development stage. Inventions turned into products have product resources like market and product. These appear in the middle of the Valley, forming the second stage of Product development. Finally, products turned into ventures possess the resources for commercialization appears on the right side of the Valley and reflects the third stage, i.e., commercialization. The Valley of Death between technical development through product development and product development and commercialization represents the chances of product failure or venture failure due to lack of resources and expertise. Startups need numerous steps to cross this Valley of death successfully. This paper aims to share these actions as guidelines for young entrepreneurs.

\section{Theoretical background}

In an entrepreneurial context, the term Valley of Death (VoD) was first used by Stephan Markham (2002), describing a firm's failure to attain sustainable business models (Markham, 2012). Figure 1 shows a typical valley of death for new startups. VoD is often used for commercialization projects of new high technologies (Budi \& Aldianto, 2020). Getting a return on investment comes first, overcoming the risk factors associated with these technologies. These risk factors are collectively referred to as Valley of Death (VoD) and are often linked as the significant reason for high-tech venture failures (Al Natsheh, 2021).

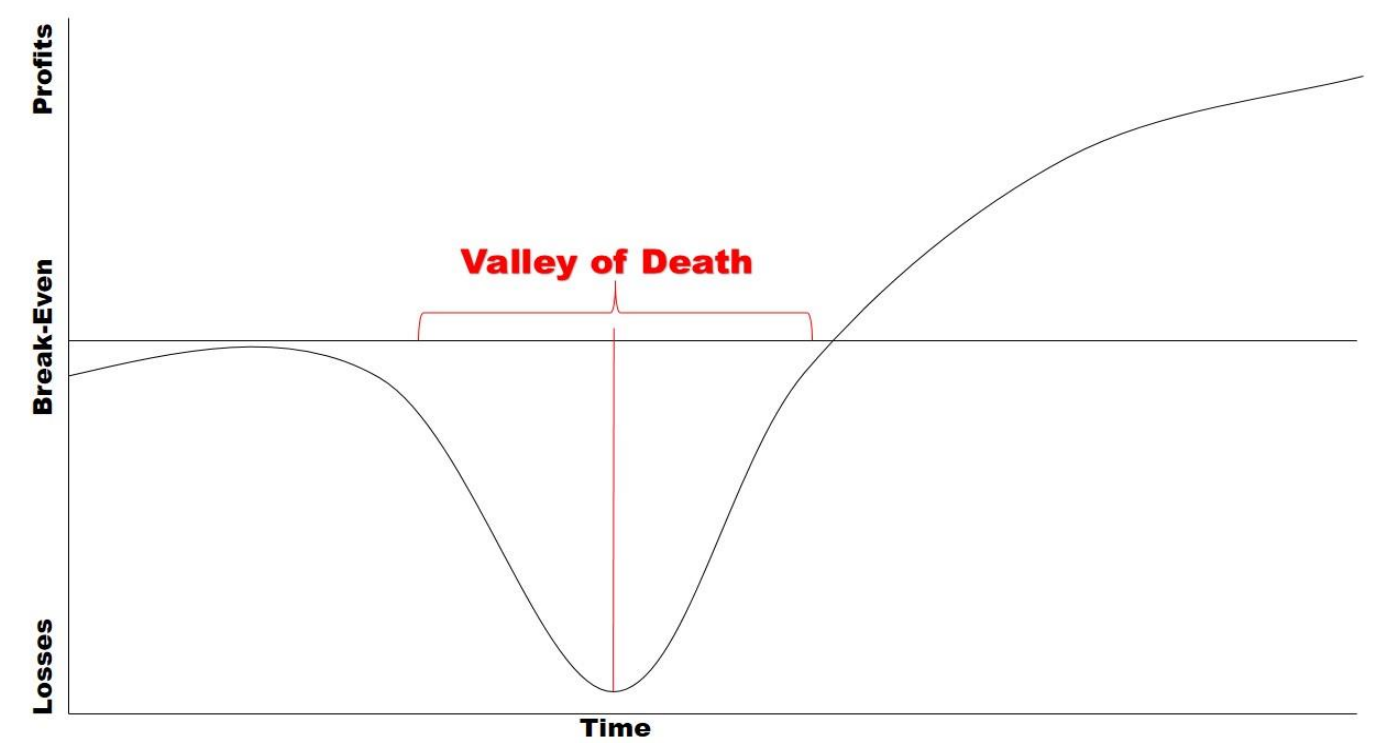

Figure 1. The Valley of Death (Source: author's contribution; adapted from Markham, 2012; McIntyre, 2014) 


\section{ENTREPRENEURSHIP AND SUSTAINABILITY ISSUES}

ISSN 2345-0282 (online) http://jssidoi.org/jesi/

2021 Volume 9 Number 1 (September)

http://doi.org/10.9770/jesi.2021.9.1(40)

Many studies are linking the Valley of Death (VoD) concept to entrepreneurs and startups, for example (Barr, Baker, Markham, \& Kingon, 2009; Verhoeff, \& Menzel, 2011; Abereijo, 2015; Takata, Nakagawa, Yoshida, Matsuyuki, Matsuhashi, Kato, \& Stevens, 2020; Etzkowitz, Mack, Schaffer, Scopa, Guo, \& Pospelova, 2020; Barron, \& Amorós, 2020; Stefanelli, Boscia, \& Toma, 2020; Calza, et al., 2020; and more recently Sung, 2021).

Different studies have suggested different entrepreneurial actions to avoid VoD. One such study had suggested that students develop commercialization skills to prepare them for success in the tech industry (Barr, et al 2009). Another study had suggested that building up one's social capital could reduce the risk of the Valley of death. The authors show that an interactive training approach can enhance social capital through the training of entrepreneurs (Verhoeff, \& Menzel, 2011). In another attempt, establishing entrepreneurial universities has been considered the solution for VoD (Abereijo, 2015); Stanford University's success could be an excellent example of an entrepreneurial university (Etzkowitz, et al., 2020). University spin-offs were also considered as a possible bridge for VoD. The appointment of a technology transfer professional (TTP) was also considered a possible solution to the problem of VoD (Takata, et al., 2020). Finally, some studies were focused on specific industry sectors like the Biopharma industry (Calza, et al., 2020) or specific to an entrepreneurship program (Barron, \& Amorós, 2020).

Many observations can be made on existing literature on VoD linking to entrepreneurship. Firstly, most of the relevant literature is specific to the industry and unable to generate generalizations. There is no significant research or conceptual model for entrepreneurial actions bridging the gap of $\mathrm{VoD}$. This research hypothesized to make a conceptual model crossing the $\mathrm{VoD}$ using the entrepreneurial ecosystem. This section aims to provide literature support for entrepreneurial actions to cross the VoD using the entrepreneurial ecosystem successfully.

There is no standard definition of entrepreneurship ecosystems among academic and practitioner groups (Stam, \& de Ven, 2021). The first component of this concept is often referred to as entrepreneurial. The concept of entrepreneurship is often narrowed down to high-growth startups or scale-ups, claiming that these are innovation and productivity growth engines. However, this claim seems too exclusive. In the literature on entrepreneurship, it has become increasingly emphasized that innovation and growth-oriented approaches are prevalent. The second component of the ecosystem is similar to a biotic community, which is defined as a complex network of living organisms interacting in various ways. A community ecology perspective considers the various roles that various institutions and organizations play in the evolution of a community. This mutualistic interdependence is often linked to the interests of various actors, such as local communities, universities, and business establishments. For instance, if a startup company wants to start a business in a particular region, its investors and local partners will develop mutually beneficial relationships. Aside from these, other actors also play critical roles in developing and sustaining an entrepreneurial ecosystem (Duan, Sandhu, \& Kotey, 2021).

The entrepreneurship ecosystem consists of many elements, converged into six higher-order domains: (1) enabling government policies and leadership, (2) availability of financial capital, (3) a conducive culture, (4) an infrastructure and institutional support from professional organizations, (5) quality of human capital, (6) venturefriendly markets for products (Isenberg, 2021). Table 1 shows domains of the entrepreneurial ecosystem. 
Table 1. Domains of Entrepreneurial Ecosystem

\begin{tabular}{|c|c|c|}
\hline Domain & Sub-Domain & Major Components \\
\hline \multirow[b]{2}{*}{ Policy } & Government & $\begin{array}{ll}\text { - } & \text { Institutions, e.g., Investment, Support } \\
\text { - } & \text { Financial Support, e.g., R\&D fund, Jumpstart funds } \\
\text { - } & \text { Regulatory Framework Incentives, e.g., Tax benefits, Bankruptcy, contract } \\
\text { enforcement, property rights, and labor }\end{array}$ \\
\hline & Leadership & $\begin{array}{ll}\text { - } & \text { Unequivocal Support } \\
\text { - } & \text { Social legitimacy } \\
\text { - } & \text { Open door for advocate } \\
\text { - } & \text { Entrepreneurship strategy } \\
\text { - } & \text { Urgency, crisis, and challenge } \\
\text { - } & \text { Research Institutions } \\
\text { - } & \text { Venture Friendly legislation, e.g., } \\
\end{array}$ \\
\hline Finance & $\begin{array}{l}\text { Financial } \\
\text { Capital }\end{array}$ & $\begin{array}{ll}\text { - } & \text { Micro-loans } \\
\text { - } & \text { Venture capital funds } \\
\text { - } & \text { Angel investors, friends, and family } \\
\text { - } & \text { Private equity } \\
\text { - } & \text { Public capital markets } \\
\text { - } & \text { Bank loans, Debt } \\
\text { - } & \text { Zero-stage venture capital } \\
\end{array}$ \\
\hline \multirow[b]{2}{*}{ Culture } & Success Stories & $\begin{array}{ll} & \text { Visible successes } \\
\text { - } & \text { Wealth generation for founders } \\
\text { - } & \text { International reputation } \\
\end{array}$ \\
\hline & Societal Norms & $\begin{array}{ll}\text { - } & \text { Tolerance of risk, mistakes, failure } \\
\text { - } & \text { Innovation, creativity, experimentation } \\
\text { - } & \text { Social status of an entrepreneur } \\
\text { - } & \text { Wealth creation } \\
\text { - } & \text { Ambition, drive, hunger } \\
\end{array}$ \\
\hline \multirow{3}{*}{ Supports } & $\begin{array}{l}\text { Infrastructure } \\
\text { Support }\end{array}$ & $\begin{array}{ll}\text { - } & \text { Telecommunications } \\
\text { - } & \text { Transportation \& logistics } \\
\text { - } & \text { Energy } \\
\text { - } & \text { Zones, incubation centers, clusters } \\
\end{array}$ \\
\hline & $\begin{array}{l}\text { Support } \\
\text { Professions }\end{array}$ & $\begin{array}{ll}- & \text { Legal } \\
- & \text { Accounting } \\
\text { - } & \text { Investment Bankers } \\
\text { - } & \text { Technical Experts, advisors } \\
\end{array}$ \\
\hline & $\begin{array}{l}\text { Non- } \\
\text { Government } \\
\text { Institutions }\end{array}$ & $\begin{array}{ll}\text { - } & \text { Entrepreneurship promotion in non-profits } \\
\text { - } & \text { Business plan contests associations } \\
\text { - } & \text { Entrepreneur-friendly associations } \\
\text { - } & \text { Conferences } \\
\end{array}$ \\
\hline \multirow{2}{*}{$\begin{array}{l}\text { Human } \\
\text { Capital }\end{array}$} & $\begin{array}{l}\text { Educational } \\
\text { Institutions }\end{array}$ & $\begin{array}{ll} & \text { General degrees (professional and academic) } \\
\text { - } & \text { Specific entrepreneurship training } \\
\end{array}$ \\
\hline & Labor & $\begin{array}{ll}- & \text { Skilled and unskilled } \\
\text { - } & \text { Serial entrepreneurs } \\
\text { - } & \text { Later-generation family } \\
\end{array}$ \\
\hline \multirow[t]{2}{*}{ Markets } & $\begin{array}{l}\text { Early } \\
\text { Customers }\end{array}$ & $\begin{array}{ll}\text { - } & \text { Early adopters for proof-of-concept } \\
\text { - } & \text { Expertise in productizing } \\
\text { - } & \text { Reference customer } \\
\text { - } & \text { First reviews } \\
\text { - } & \text { Distribution channels } \\
\end{array}$ \\
\hline & Networks & $\begin{array}{ll}- & \text { Entrepreneur's networks } \\
\text { - } & \text { Diaspora networks } \\
\text { - } & \text { Multinational corporations } \\
\end{array}$ \\
\hline
\end{tabular}


ENTREPRENEURSHIP AND SUSTAINABILITY ISSUES

ISSN 2345-0282 (online) http://jssidoi.org/jesi/

2021 Volume 9 Number 1 (September)

http://doi.org/10.9770/jesi.2021.9.1(40)

Table 2 shows lessons learned to cross the Valley of death using entrepreneurial ecosystems. These lessons are extracted from earlier studies.

Table 2. Lessons learned to Cross the Valley of Death - Entrepreneurial Ecosystem

\begin{tabular}{|l|l|}
\hline \multicolumn{1}{|c|}{ Entrepreneurial Action } & \multicolumn{1}{c|}{ Reference } \\
\hline Understand the local entrepreneurial ecosystem. & (Calza, et al., 2020; Jucevičius, et al., 2016). \\
\hline $\begin{array}{l}\text { Use heuristics or rules of thumb as a checklist to mitigate risks, reduce } \\
\text { uncertainty and make a decision }\end{array}$ & (Markham, 2002). \\
\hline
\end{tabular}

Role of Country Governments in building Entrepreneurial Ecosystems: Governments play a pivotal role in establishing an entrepreneurial ecosystem (Chandra, \& Fealey, 2009). There are three different governance models for the entrepreneurial ecosystem: top-down, bottom-up, and hybrid (Figure 2). First, the top-down method, as exhibited by Japanese and Swedish governments, provide subsidies in research and promote technology commercialization of the startups (Lynn, \& Kishida, 2004) or establish mechanisms of direct interactions between universities, research centers, and relevant industrial sectors (Sun, Zhang, Cao, Dong, \& Cantwell, 2019). The second method, the bottom-up method, as exhibited by the U.S. government by setting up competition-based rules to facilitate linkages and networks among universities, entrepreneurs, accelerators, venture capital, large firms, and consultants (Sun et al., 2019; Pauwels, Clarysse, Wright, \& Van Hove, 2016; Belz, Terrile, Zapatero, Kawas, \& Giga, 2019). Finally, the third approach is a hybrid method by combing the strengths of top-down and bottom-up methods, mainly observed in developing countries, including China, Taiwan, and Singapore (Sun et al., 2019).
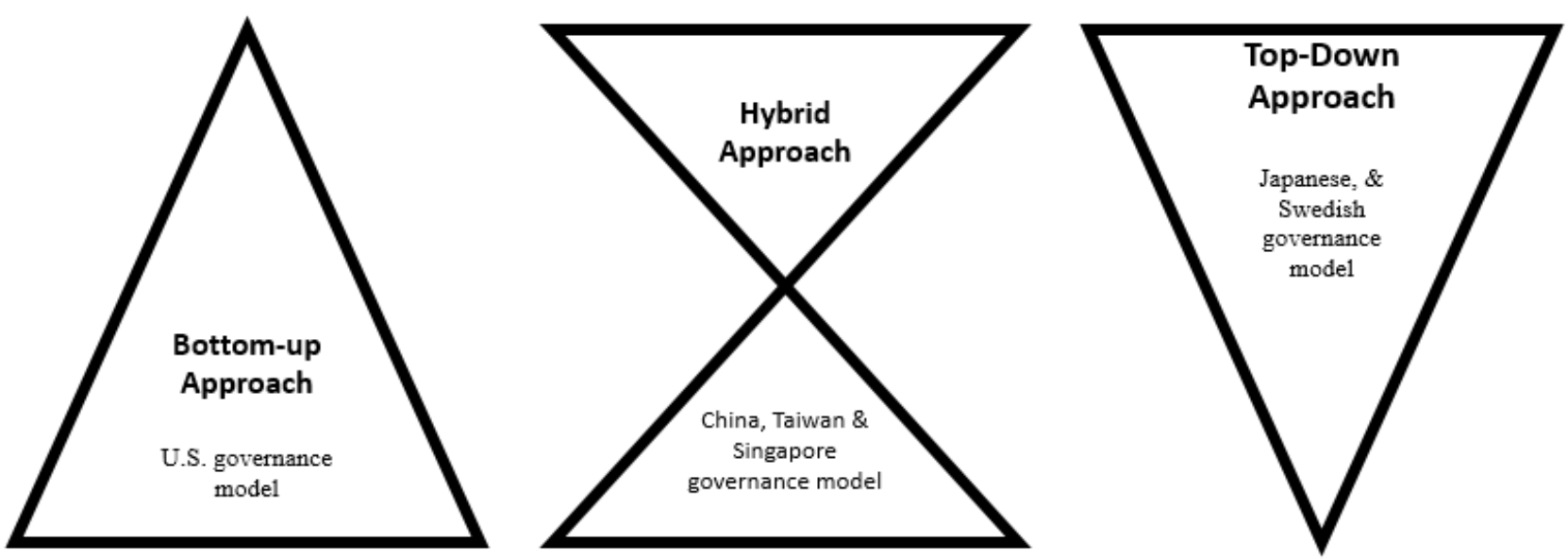

Figure 2. Entrepreneurial Ecosystem - Role of Country Government Source: author's contribution; adapted from Sun et al., 2019

The government acts as a 'planner' in the top-down and directly creates mechanisms of commercialization. In contrast, the government sees its position as more of a 'facilitator' in the bottom-up approach and encourages innovation through market processes, such as indirect incentives (Sun et al., 2019). Apart from these patronizing roles, government agencies also play a regulatory role. This role may vary from country to country and industry to industry. Table 3 presents governments' role in using entrepreneurial ecosystems to cross the Valley of death successfully. 


\section{ENTREPRENEURSHIP AND SUSTAINABILITY ISSUES}

ISSN 2345-0282 (online) http://jssidoi.org/jesi/ 2021 Volume 9 Number 1 (September) http://doi.org/10.9770/jesi.2021.9.1(40)

Table 3. Lessons learned to Cross the Valley of Death - Role of Government

\begin{tabular}{|l|l|}
\hline \multicolumn{1}{|c|}{ Entrepreneurial Action } & \multicolumn{1}{|c|}{ Reference } \\
\hline $\begin{array}{l}\text { Understand the government rules, procedures, and incentives (like tax benefits, grants) for } \\
\text { similar startups. }\end{array}$ & (Shinkle, \& Suchard, 2019; Minniti, 2008) \\
\hline Join the local entrepreneurial network. & (Hallen, et al., 2020) \\
\hline Join business incubators at an early stage & (Siddiqui et al., 2018). \\
\hline Join business accelerator programs at a later stage. & (Halt, et al., 2017; Rai, et al., 2008) \\
\hline Understand the intellectual property rights (like Patents, Copyrights) for similar projects. & (Rai, et al., 2008) \\
\hline Secure intellectual property (I.P.) rights as soon as possible. &
\end{tabular}

Role of Leadership in Crossing the Valley of Death: One of the most important reasons for the innovation project failure is the lack of leadership (Markham, 2002; Schön, 1963). Leadership plays a pivotal role in the early stages of any startup and has a significant and positive effect on startup further performance (Zaech, \& Baldegger, 2017). However, within the new startups, those engineers or scientists typically play this role busy in new product development or new feature development, and they have a lack motivation to commercialize their ideas (Upadhyayula, et al., 2018; Dobrenkov, et al., 2017). Therefore, there might be a shift in a leadership role from scientists to 'innovation champions' (Markham, 2002) or, more precisely, to the team members having a more entrepreneurial mindset once the innovation moves towards product development or commercialization stages. Table 4 shows the role of startup leadership in crossing the Valley of death successfully.

Table 4. Lessons learned to Cross the Valley of Death - Leadership's Role

\begin{tabular}{|l|l|}
\hline \multicolumn{1}{|c|}{ Entrepreneurial Action } & \multicolumn{1}{c|}{ Reference } \\
\hline Understand the role of leadership in startup performance. & (Zaech, \& Baldegger, 2017) \\
\hline Shift the leadership role from a scientific mindset to a more entrepreneurial mindset & (Markham, 2002) \\
\hline
\end{tabular}

Role of Financial Capital in Crossing the Valley of Death: Turning innovations into commercial products typically financed by many entities in different Valley of Death stages. It starts with scientist's won savings and support from family and friends (Mcintyre, 2014). In subsequent stages, the innovation teams may get financial support from angel investors or venture capitalists (Figure 3). Angel investors are willing to take risks by investing in new ventures and providing capital for startup or expansion. In addition, they can instantly provide small-to-mid-size amounts as an investment with a higher rate of return than would be given by more traditional investments (Cavallo, et al., 2019).

Venture capitalists (VC) are private equity investors who can invest mid-size capital to new companies exhibiting high growth potential in exchange for an equity stake (Mcintyre, 2014). Also, provide bridge finance to startups that wish to expand and go for their IPO but do not have access to equities markets. Finally, at later stages in commercialization, either through an initial public offering (IPO) or through bank borrowing, the innovation team can raise funds for their operations. An initial public offering (IPO) refers to offering shares to the public investor to raise capital (Shinkle, \& Suchard, 2019). It is an expensive option but typically meets a large funding target amount with having detailed disclosure requirements. Table 5 shows lessons learned for financial capital in crossing the Valley of death successfully. 


\section{ENTREPRENEURSHIP AND SUSTAINABILITY ISSUES}

ISSN 2345-0282 (online) http://jssidoi.org/jesi/

2021 Volume 9 Number 1 (September)

http://doi.org/10.9770/jesi.2021.9.1(40)

Table 5. Lessons learned to Cross the Valley of Death - Financial Capital

\begin{tabular}{|l|l|}
\hline \multicolumn{1}{|c|}{ Entrepreneurial Action } & \multicolumn{1}{|c|}{ Reference } \\
\hline Understand the financial capital for the startup. & (Gejun, 2021) \\
\hline Use business plan/feasibility to attract stakeholders (investors, customers, authorities) & (Barr, et al. 2009) \\
\hline Understand the risks and decision-making choices. & \multirow{2}{*}{ (Barr, et al 2009, Tversky \& Kahneman, 2004) } \\
\hline Acquire resources to mitigate risk. & \multirow{2}{*}{ (Savaneviciene, et al., 2015) } \\
\cline { 1 - 1 } Contact angel investors in the early stages. & \\
\hline Contact venture capitalists in late stages. & \\
\hline Choose venture capitalists from the entrepreneurial ecosystem. &
\end{tabular}

Role of Culture in Crossing the Valley of Death: Culture has been classified as an essential component of the entrepreneurship ecosystem (Isenberg, 2011). It influences the participants' level of risk acceptance and creativity, and it can also enforce one particular activity or another (Dubina, \& Ramos, 2016). Culture is learned, not inherited, and comes from the social environment, and the differences between members of a group are reflected in their culture (Hofstede, Hofstede, \& Minkov, 2010). These similarities are passed down from generation to generation. It is also common for parents to teach their children about values. Those who prefer a particular state of things are also known as appropriate individuals. Japanese culture is highly risk-averse. This makes it hard to imagine a type of business activity that is suitable for Japanese consumers. Literature also supports the idea that regional entrepreneurial culture and early-stage entrepreneurial activity can be linked (Bosma, \& Holvoet, 2015). Culture has a lot to offer when it comes to entrepreneurship (Donaldson, 2021). The cultural aspects within leading entrepreneurial ecosystems can be divided into various aspects such as the tolerance of risk, the preference for starting a business, the positive perception of entrepreneurship, etc. Table 6 shows lessons learned for regional culture in crossing the Valley of death successfully.

Table 6. Lessons learned to Cross the Valley of Death - Culture

\begin{tabular}{|l|l|}
\hline \multicolumn{1}{|c|}{ Entrepreneurial Action } & \multicolumn{1}{c|}{ Reference } \\
\hline Understand the regional entrepreneurial culture. & (Donaldson, 2021, Bosma, \& Holvoet, 2015) \\
\hline Join business incubators at an early stage & \multirow{2}{*}{ (Siddiqui, et al., 2018). } \\
\hline Join business accelerator programs at a later stage. & \\
\hline
\end{tabular}

Role of Support Services in Crossing the Valley of Death: Various support services are needed for entrepreneurial ecosystems, which may be classified into three broad classes; (a) infrastructure support, (b) professional support, and (c) development support (Markham, 2002). Infrastructure support reflects the essential physical and organizational structures and facilities (e.g., telecommunications, buildings, roads, energy, water, power supplies) needed to operate a venture. Professional support includes services needed for a venture's launch and operations (e.g., legal, accounting, advertising, information technology, etc.). Finally, development support services help startups develop and accelerate their growth by providing training, business support, and office space (Siddiqui, et al., 2018). These development supports are either in the form of business incubators and business accelerators. Business incubators help new ideas, novice entrepreneurs, and new startup companies develop by providing services such as management, training, or office space (Hausberg, \& Korreck, 2021). Business accelerators are programs that give developing companies access to mentorship, investors, and other support services that help them become stable, self-sufficient businesses. Startups that use the services of business accelerators are typically those having moved beyond the earliest stages of getting established (Hausberg, \& Korreck, 2021). Table 7 shows lessons learned for support services in crossing the Valley of death successfully. 


\section{ENTREPRENEURSHIP AND SUSTAINABILITY ISSUES}

ISSN 2345-0282 (online) http://jssidoi.org/jesi/ 2021 Volume 9 Number 1 (September) http://doi.org/10.9770/jesi.2021.9.1(40)

Table 7. Lessons learned to Cross the Valley of Death - Support Services

\begin{tabular}{|l|l|}
\hline \multicolumn{1}{|c|}{ Entrepreneurial Action } & \multicolumn{1}{|c|}{ Reference } \\
\hline Understand the support services for similar startups. & (Prasetyo, 2020) \\
\hline $\begin{array}{l}\text { Acquire infrastructure support services (e.g., telecommunications, buildings, roads, energy, water, power } \\
\text { supplies) at early stages. }\end{array}$ & (Markham, 2002) \\
\hline Acquire professional support (e.g., Legal, Accounting, Advertising, I.T.) using 'outsourcing.' & (Siddiqui, et al., \\
\hline $\begin{array}{l}\text { Choose the startup location based on the availability of infrastructure support (e.g., telecommunications, } \\
\text { buildings, roads, energy, water, power supplies) }\end{array}$ & 2018). \\
\hline Look for business incubators with experienced staff and mentors. & \\
\hline Look for faculty-led business incubators. & (Siddiqui, et al., \\
\hline Look for business incubators with a built-operate-transfer model. & 2018). \\
\hline Join business incubators at an early stage. & \\
\hline Join business accelerator programs at a later stage. & \\
\hline Look for business incubators with support services. & \\
\hline Look for business incubators with network support. & \\
\hline Look for business incubators with financial support. & \\
\hline Look for business incubators with economic development. & \\
\hline Look for business incubators with greater alumni success. & \\
\hline
\end{tabular}

Role of Human Capital in Crossing the Valley of Death: The role of human capital in innovation has always been given paramount importance (McMullan, \& Melnyk, 1988; Gunasekara, 2006), especially the role of universities and tertiary education institutions (Owen-Smith, \& Powell, 2003). The decisive role of human capital is the primary key in driving economic growth both directly and indirectly (Prasetyo, 2020). Universities are often considered an 'engine' for innovation (Etzkowitz, 2008) and as a 'catalyst' for technology development (DaSilva, 1997). Integrating both the 'innovation engine' and 'sustainability catalyst' roles is best reflected in their engagement in the entrepreneurial ecosystem. In entrepreneurial ecosystems, they play a foundation role or the first stage of the ecosystem. In top-down countries, research has been done in universities or affiliated research centers and funded mainly by the public sector resources, while in bottom-up countries like the USA, the funding to universities and research centers is through grants, incentives, and support for commercialization (Sun et al., 2019).

The quality and quantity of employees a company has is its human capital domain and is represented by its environment. The human capital domain is a collection of components that affect the pace of business growth. The components include the management and technical expertise, entrepreneurial spirit, the availability of a skilled immigrant workforce, and the ability to outsource. Education of the human capital is a critical component of an entrepreneur-friendly ecosystem. It can help individuals develop their knowledge and skills in areas such as entrepreneurship. The importance of entrepreneurship can be seen in the various ways that universities promote it. For instance, they play a vital role in helping new companies get off the ground. Table 8 shows lessons learned for human capital in crossing the Valley of death successfully. 
Table 8. Lessons learned to Cross the Valley of Death - Human Capital

\begin{tabular}{|l|l|}
\hline \multicolumn{1}{|c|}{ Entrepreneurial Action } & \multicolumn{1}{|c|}{ Reference } \\
\hline Understand the role of universities and research centers in startup performance. & (Son, et al., 2020; Barr, et al. 2009) \\
\hline Attend formal training on entrepreneurship. & (Johannisson, et al., 1998; Taatila, 2010) \\
\hline Attend formal education, either academic or professional. & (Johannisson, 1991; Putta, 2014) \\
\hline Look for faculty-led university business incubators & (Siddiqui, et al., 2018). \\
\hline Participate in entrepreneurship expo, conferences, or other events. & (Jauhiainen, 2021) \\
\hline Participate in business plan competitions. & (Qureshi, Saeed, \& Wasti, 2016). \\
\hline Develop a business model canvas instead of writing a business plan. & (Türko, 2016; Jackson, et al., 2015; Siddiqui, \\
\hline $\begin{array}{l}\text { Spend more time to gather and process information and finalize the business } \\
\text { feasibility study. }\end{array}$ & (Barr, et al. 2009) \\
\hline
\end{tabular}

Role of Markets and Networks in Crossing the Valley of Death: The markets domain refers to people willing to pay for a product or service (Isenberg, 2011). This domain is often referred to as the customer base. Establishing an ecosystem with accessible markets is an essential step for businesses to grow. Therefore, customers' potential is a crucial aspect to consider when assessing the competitive advantage, and it is a crucial component to consider when selecting a vendor. Table 9 shows marketing lessons learned to cross the Valley of death.

Table 9. Lessons learned to Cross the Valley of Death - Markets

\begin{tabular}{|c|c|}
\hline Entrepreneurial Action & Reference \\
\hline Understand markets, competitors, and customers. & (Isenberg, 2011) \\
\hline Understand the commercial value of the research project/product. & \multirow{3}{*}{ (Markham, 2002) } \\
\hline Transform research/idea into a saleable product or at least prototype. & \\
\hline Acquire the resources needed to establish a potential product/idea. & \\
\hline Understand mass-scale production/operations or scale-up or for startups. & (Cavallo, et al., 2019) \\
\hline Use unconventional/ innovative methods to understand customers. & (Stam, \& Ven, 2021) \\
\hline Use market intelligence rather than market research to understand competitors. & (Falahat, et al., 2020) \\
\hline Join the innovative distribution channels. & (Barr, et al 2009; Brettel, et al., 2011). \\
\hline Reach to customers in innovative manners. & \multirow{3}{*}{ (Hermanto, 2017) } \\
\hline Reach to reference customers and early influencers. & \\
\hline Find early adopters as a customer for the proof of concept & \\
\hline Develop innovative promotion techniques. & (Abdul-Rahim, \& Saad, 2015) \\
\hline Join the networks of multinational corporations & (Williams, \& Lee, 2009) \\
\hline
\end{tabular}

The market domain is a critical component of consumers' willingness to buy products and services (Isenberg, 2011). This domain is often represented by the size of the company and its geographical reach. Another most important issue to cross the Valley of death is the commercialization of the product. Entrepreneurs must understand the commercial value of the research project/product, transform research/idea into a saleable product, or at least prototype and acquire the resources needed to establish a potential product/idea (Markham, 2002). 


\section{Research objective and methodology}

This paper aims to share the experiences of guiding young entrepreneurs for their entrepreneurial initiatives. Initially, 60 short entrepreneurial actions were extracted from earlier studies (Table $1-7$ ), which help the young entrepreneurs to cross the Valley of death successfully using the entrepreneurial ecosystem. These entrepreneurial actions were validated through a two-staged process. In the first stage, an online survey was sent to a limited number of experts to validate the entrepreneurial actions. They were asked to rate each item on a scale of one to five, one being the least critical and five being the most critical entrepreneurial action. Then, they were instructed to consider these entrepreneurial actions in the earlier stages of a new startup to cross the Valley of death. Participants of this expert survey include faculty members of business school teaching entrepreneurship, experienced entrepreneurs affiliated with business incubators as 'mentors' or 'executive in residence,' directors/managers/senior staff of business incubators, past attendees of the business incubation, and acceleration programs. Table 10 presents the demographic details of participants of this expert survey $(\mathrm{N}=16)$.

Table 10. Demographic details of participants $(\mathrm{N}=16)$

\begin{tabular}{|c|l|c|c|}
\hline Variable & \multicolumn{1}{|c|}{ Category } & Frequency & Percentage \\
\hline \multirow{4}{*}{ Age } & Up to 34 years & 4 & $25.0 \%$ \\
\cline { 2 - 4 } & $35-44$ years & 8 & $50.0 \%$ \\
\cline { 2 - 4 } & 45-54 years & 2 & $12.5 \%$ \\
\cline { 2 - 4 } & Above 55 years & 2 & $12.5 \%$ \\
\hline \multirow{3}{*}{ Gender } & Male & 6 & $62.5 \%$ \\
\cline { 2 - 4 } & Female & 10 & $37.5 \%$ \\
\hline \multirow{4}{*}{ Profession* } & Entrepreneur & 5 & $31.3 \%$ \\
\cline { 2 - 4 } & Incubator Manager/Staff & 4 & $25.0 \%$ \\
\cline { 2 - 4 } & Entrepreneurship Professor/Faculty & 4 & $25.0 \%$ \\
\cline { 2 - 4 } & Entrepreneurship Mentor & 1 & $6.25 \%$ \\
\cline { 2 - 4 } & Venture Capitalist/Angel Investor & $62.5 \%$ \\
\hline
\end{tabular}

* Multiple professions allowed for each participant; total may not be $100 \%$

Based on survey responses, some entrepreneurial actions secured more petite than a 3.0 rating out of 5.0 were dropped from the further analysis. Few observations are made here. Firstly, four domains of the entrepreneurial ecosystem were replicated in this study namely government policies and leadership, financial capital, support services, and markets. The culture was partially replicated, while the experts did not validate the human capital. Secondly, those items dropped from the study were considered invalid for this study but can be used in others studies. These entrepreneurial actions may not be directly helping entrepreneurs get out of the Valley of death, hence dropped from the further analyses. Thirdly, few observations make sense. For example, faculty-led business incubators or build-operate-transfer models of business incubators were not theoretically possible. Experts were not convinced that formal or professional education needed to cross the Valley of death; however, the entrepreneurial mindset was critical. The role of universities in the performance of startups is well established, but results do not favor them critical for Valley of death. Business plan competitions, conferences, business model canvas, or feasibility studies may not be helpful to cross the Valley of death. Those items that pass this validity test are considered critical to cross the Valley of death successfully. Table 11 presents items dropped from this analysis. 
Table 11. List of dropped items from the analysis $(\mathrm{N}=16)$

\begin{tabular}{|l|l|l|}
\hline \multicolumn{1}{|c|}{ Entrepreneurial Action } & \multicolumn{1}{|c|}{\begin{tabular}{c}
\multicolumn{1}{|c|}{ Reference } \\
Score
\end{tabular}} \\
\cline { 1 - 2 } Look for faculty-led university business incubators & \multirow{2}{*}{ (Siddiqui, et al., 2018). } & 1.65 \\
\hline Look for business incubators with a built-operate-transfer model. & 1.75 \\
\hline $\begin{array}{l}\text { Spend more time to gather and process information and finalize the business } \\
\text { feasibility study. }\end{array}$ & (Barr, et al. 2009) & 2.21 \\
\hline Participate in business plan competitions. & (Qureshi, Saeed, \& Wasti, 2016). & 2.28 \\
\hline Participate in entrepreneurship expo, conferences, or other events. & (Jauhiainen, 2021) & 2.59 \\
\hline Attend formal education, either academic or professional. & (Johannisson, 1991; Putta, 2014) \\
\hline Attend formal training on entrepreneurship. & (Johannisson, et al., 1998; Taatila, 2010) & 2.78 \\
\hline Develop a business model canvas instead of writing a business plan. & $\begin{array}{l}\text { (Türko, 2016; Jackson, et al., 2015; } \\
\text { Siddiqui, 2021). }\end{array}$ \\
\hline Understand the role of universities and research centers in startup performance. & (Son, et al., 2020; Barr, et al. 2009) & 2.9 \\
\hline
\end{tabular}

\section{Results}

At a later stage, some of the remaining items were combined to form a single item and re-arranged in such a way to answer three basic questions. These three essential questions include; (1) What lessons need to be understood by young entrepreneurs? (2) How to implement these actions? (3) When to implement these actions. Table 12 presents validated entrepreneurial actions to cross the Valley of death.

Table 12. Validated Entrepreneurial Actions to Cross the Valley of Death

\begin{tabular}{|c|c|c|c|}
\hline $\begin{array}{l}\text { Type of } \\
\text { Action }\end{array}$ & $\begin{array}{l}\text { Entrepreneurial Action } \\
\text { Reference }\end{array}$ & $\begin{array}{l}\text { Type of } \\
\text { Action }\end{array}$ & $\begin{array}{l}\text { Entrepreneurial Action } \\
\text { Reference }\end{array}$ \\
\hline \multirow{3}{*}{ What } & \multirow{3}{*}{$\begin{array}{l}\text { Understand the entrepreneurial } \\
\text { ecosystem (Calza, et al., 2020; } \\
\text { Jucevičius, et al., 2016). }\end{array}$} & When & $\begin{array}{l}\text { Join business incubators at an early stage and join business accelerator } \\
\text { programs at a later stage (Siddiqui, et al., 2018). }\end{array}$ \\
\hline & & How & $\begin{array}{l}\text { Look for Business incubators with experienced staff; and faculty-led } \\
\text { incubators; and a built-operate-transfer model (Siddiqui, et al., 2018). }\end{array}$ \\
\hline & & How & $\begin{array}{l}\text { Look for Business incubators with support services; network support; } \\
\text { financial support; economic development; alumni success (Siddiqui, et al., } \\
\text { 2018). }\end{array}$ \\
\hline \multirow{2}{*}{ What } & \multirow{2}{*}{$\begin{array}{l}\text { Understand the government rules, } \\
\text { procedures, and incentives (like tax } \\
\text { benefits, grants) for similar startups. } \\
\text { (Shinkle, \& Suchard, 2019; Minniti, } \\
\text { 2008). }\end{array}$} & How & $\begin{array}{l}\text { Join business incubators at an early stage and join business accelerator } \\
\text { programs at a later stage (Siddiqui, et al., 2018). }\end{array}$ \\
\hline & & How & Join the local entrepreneurial network. (Hallen, et al., 2020). \\
\hline What & $\begin{array}{l}\text { Understand the Intellectual Property } \\
\text { Rights (like Patents, Copyrights) for } \\
\text { similar projects. (Halt, et al., 2017; } \\
\text { Rai, et al., 2008). }\end{array}$ & When & $\begin{array}{l}\text { Secure Intellectual Property (I.P.) rights as soon as possible. (Rai, et al., } \\
\text { 2008). }\end{array}$ \\
\hline What. & $\begin{array}{l}\text { Understand the role of leadership in } \\
\text { startup performance. (Zaech, \& } \\
\text { Baldegger, 2017) }\end{array}$ & How & $\begin{array}{l}\text { Shift the leadership role from a scientific mindset to a more } \\
\text { entrepreneurial mindset (Markham, 2002) }\end{array}$ \\
\hline \multirow{2}{*}{ What } & \multirow{2}{*}{$\begin{array}{l}\text { Understand the financial capital for } \\
\text { the startup. (Gejun, 2021) }\end{array}$} & How & $\begin{array}{l}\text { Use business plan/feasibility to attract stakeholders (employees, investors, } \\
\text { customers, authorities) (Barr, et al. 2009) }\end{array}$ \\
\hline & & How & $\begin{array}{l}\text { Look for venture capitalists from the regional entrepreneurial ecosystem } \\
\text { (Savaneviciene, et al., 2015). }\end{array}$ \\
\hline
\end{tabular}


ENTREPRENEURSHIP AND SUSTAINABILITY ISSUES

ISSN 2345-0282 (online) http://jssidoi.org/jesi/ 2021 Volume 9 Number 1 (September) http://doi.org/10.9770/jesi.2021.9.1(40)

\begin{tabular}{|c|c|c|c|}
\hline & & When & $\begin{array}{l}\text { Contact angel investors in the early stages and venture capitalists in the } \\
\text { late stages. (Savaneviciene, et al., 2015). }\end{array}$ \\
\hline \multirow{2}{*}{ What } & \multirow{2}{*}{$\begin{array}{l}\text { Understand the risks and decision- } \\
\text { making choices. (Barr, et al 2009, } \\
\text { Tversky \& Kahneman, 2004). }\end{array}$} & How & $\begin{array}{l}\text { Acquire resources to mitigate risk. (Barr, et al 2009, Tversky \& } \\
\text { Kahneman, 2004). }\end{array}$ \\
\hline & & How & $\begin{array}{l}\text { Use heuristics or rules of thumb as a checklist to mitigate risks, reduce } \\
\text { uncertainty and make a decision (Markham, 2002). }\end{array}$ \\
\hline \multirow{2}{*}{ What } & \multirow{2}{*}{$\begin{array}{l}\text { Understand the regional } \\
\text { entrepreneurial culture. (Donaldson, } \\
\text { 2021, Bosma, \& Holvoet, 2015) }\end{array}$} & How & $\begin{array}{l}\text { Join business incubators at an early stage and join business accelerator } \\
\text { programs at a later stage (Siddiqui, et al., 2018). }\end{array}$ \\
\hline & & How & Join the local entrepreneurial network. (Hallen, et al., 2020). \\
\hline \multirow{3}{*}{ What } & \multirow{3}{*}{$\begin{array}{l}\text { Understand the support services for } \\
\text { similar startups. (Prasetyo, 2020) }\end{array}$} & How & $\begin{array}{l}\text { Acquire Professional Support (e.g., Legal, Accounting, Advertising, I.T.) } \\
\text { using 'outsourcing.' (Markham, 2002). }\end{array}$ \\
\hline & & Where & $\begin{array}{l}\text { Choose the location based on the availability of Infrastructure Support } \\
\text { (e.g., telecommunications, buildings, roads, energy, water, power } \\
\text { supplies) (Markham, 2002). }\end{array}$ \\
\hline & & When & $\begin{array}{l}\text { Acquire support services (e.g., telecommunications, buildings, roads, } \\
\text { energy, water, power supplies) at early stages. (Markham, 2002). }\end{array}$ \\
\hline \multirow{8}{*}{ What } & \multirow{8}{*}{$\begin{array}{l}\text { Understand markets, customers \& } \\
\text { competitors }\end{array}$} & How & $\begin{array}{l}\text { Use unconventional/ innovative methods to understand customers. (Stam, } \\
\& \text { Ven, 2021) }\end{array}$ \\
\hline & & How & Use market intelligence to understand competitors. (Falahat, et al., 2020). \\
\hline & & How & Reach to customers in innovative manners. (Hermanto, 2017) \\
\hline & & How & Reach to reference customers and early influencers. (Hermanto, 2017) \\
\hline & & How & $\begin{array}{l}\text { Find early adopters as a customer for the proof of concept. (Hermanto, } \\
\text { 2017) }\end{array}$ \\
\hline & & How & $\begin{array}{l}\text { Join the innovative distribution channels. (Barr, et al 2009; Brettel, et al., } \\
\text { 2011). }\end{array}$ \\
\hline & & How & Develop innovative promotion techniques. (Abdul-Rahim, \& Saad, 2015) \\
\hline & & How & Join the networks of multinational corporations (Williams, \& Lee, 2009) \\
\hline \multirow{3}{*}{ What } & \multirow{3}{*}{$\begin{array}{l}\text { Understand the commercial value of } \\
\text { the research project/product. } \\
\text { (Markham, 2002). }\end{array}$} & How & $\begin{array}{l}\text { Acquire the resources needed to establish a potential product/idea. } \\
\text { (Markham, 2002). }\end{array}$ \\
\hline & & How & $\begin{array}{l}\text { Transform research/idea into a saleable product or at least prototype. } \\
\text { (Markham, 2002). }\end{array}$ \\
\hline & & How & $\begin{array}{l}\text { Scale-up or mass-scale production/operations for startups. (Cavallo, et al., } \\
\text { 2019). }\end{array}$ \\
\hline
\end{tabular}

Figure 3 presents a timeline of entrepreneurial actions to cross the Valley of death. The X-axis represents the period while Y-axis shows the income of the startup is placed and presented in two halves, i.e., profits and losses. 


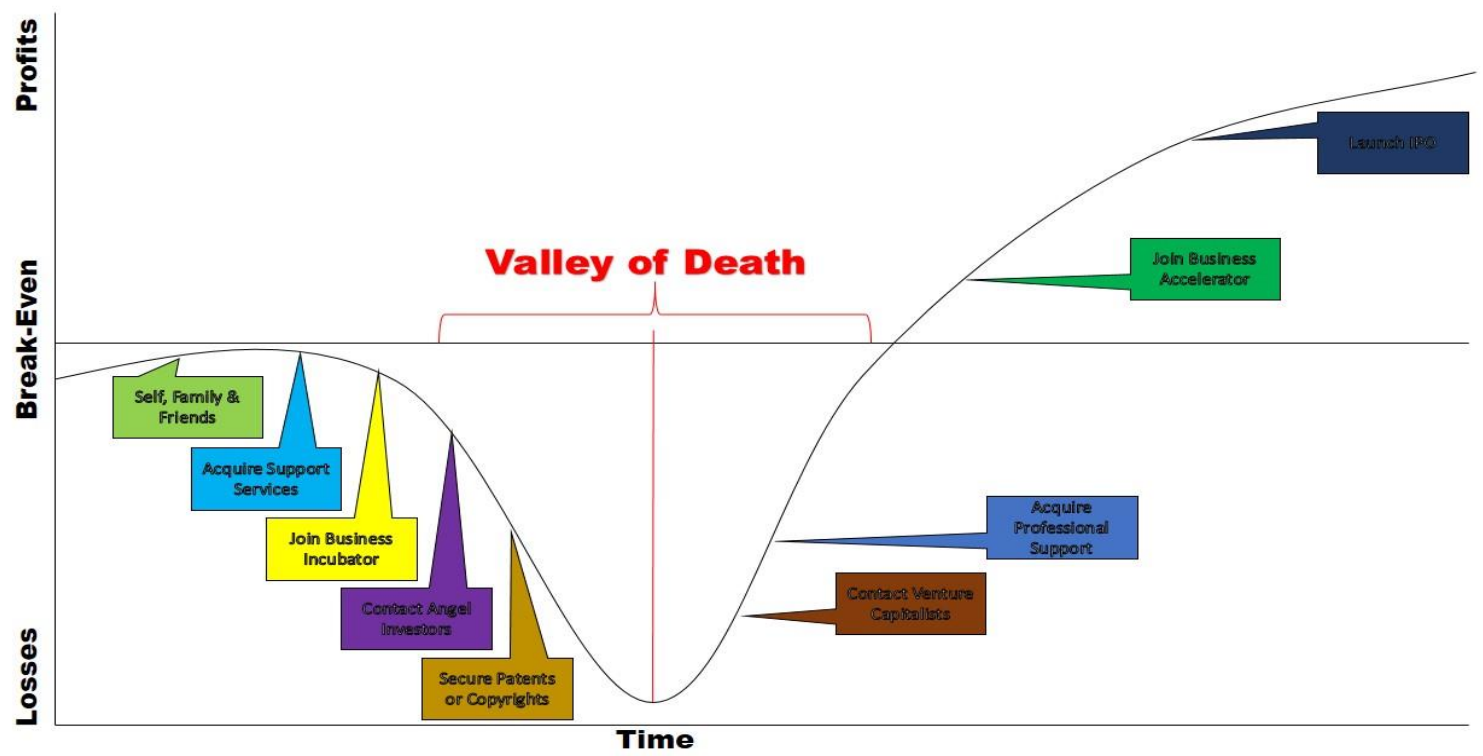

Figure 3. Valley of Death - Timeline of Entrepreneurial Actions (Source: author's contribution; adopted from McIntyre, 2014).

Several entrepreneurial actions are placed across the timeline, like self, family, and friends are usually contacted in earlier days of startup to fund the project. Next, young entrepreneurs are advised to join business incubators, certain I.P. rights, and contact angel investors to get funds without collateral. Finally, venture capitalists usually are contacted at later stages, followed by business accelerator programs. Few entrepreneurial actions like offering initial public offering and getting funds through banks are subsequent activities. Meanwhile, ideas are transformed into products and reached to markets.

\section{Conclusions and Recommendations}

This study provides recommendations in the form of guidelines for young entrepreneurs to cross the Valley of death successfully. These are generic recommendations with minimum influence on industrial sectors. Recommendations of this study are presented here as different domains of the entrepreneurial ecosystem.

Policy: Before transforming an idea into a saleable product or service, entrepreneurs must understand their entrepreneurial ecosystem and governmental support for startups. In order to understand the local or regional entrepreneurial ecosystem, entrepreneurs must join business incubators and local entrepreneurial networks. This will enhance their knowledge of government rules and procedures for new startups.

The first and foremost activity needed to cross the Valley of death is a mindset change. Within the technology development phase, it is usually a scientific mindset that works well, but crossing the Valley of death needs a more entrepreneurial mindset. It is an exciting phenomenon. Unfortunately, there is no formal innovation championship; universities and R\&D centers do not hire someone as an innovation champion or an entrepreneurial mindset. However, these 'innovation champions' or 'entrepreneurial minds' take charge voluntarily and become informal leaders of the innovation team. While they remain without official powers, their entrepreneurial mindset takes the risk beyond the comprehension of their colleagues. They persuade their team members for the positive feasibility of the project by providing them vision and direction to proceed and manage and acquire resources for the project. Sometimes they are naturally talented entrepreneurs, but they have to acquire new skills most of the time after realizing their new role. Alternatively, persons with such qualities may 


\section{ENTREPRENEURSHIP AND SUSTAINABILITY ISSUES}

ISSN 2345-0282 (online) http://jssidoi.org/jesi/

2021 Volume 9 Number 1 (September)

http://doi.org/10.9770/jesi.2021.9.1(40)

be hired as 'consultants' to the innovation team, or the innovation team may join business incubators and accelerators to overcome their deficiencies.

The most critical activity in crossing the Valley of death is to manage I.P. rights. It refers to creating a systematic process to make invention disclosure, allowing the patent review committee or stakeholders to evaluate the market potential. It also deals with I.P. protection, including drafting and filing a patent application and deciding which countries or regions I.P. should be protected and enforced. According to U.S. Patent and Trademark Office (2020), more than $90 \%$ of all patents granted are utility patents (the US. Patent and Trademark Office, 2020). A 'utility patent' is awarded to an invention, discovering a new or improvement in any machine, manufacturing process, the composition of matter, or process.

The value of innovation depends on the patentability of the innovation; typically, patentable innovations fetch higher market value due to their protection. However, the value of any innovation is the present value of all cash inflows by selling products under the patent and getting licensing fees from licensees of the innovation.

Financial Capital: The second most crucial activity for any innovation team is managing their financial capital. Turning innovations into commercial products typically financed from the outset by equity investments, not by bank loans. In the initial stages, scientists or inventors try to finance their ventures themselves, either with their savings or by working somewhere else as a part-time employee or with the help of family and friends, who are usually close to the scientist or inventor and believe in the invention. The amounts are generally small and considered soft loans. When an invention takes the shape of a commercial product in the subsequent stage, Angel Investors provide finance. When the product has shaped up, and the company has been formulated in the next stage, Venture Capitalists provide large amounts of investment. Subsequently, if a company wishes to offer its shares to the general public through Initial Public Offering, it can secure significant investments at lower financial costs. Banks do not provide loans in the initial stages of any venture; instead, they provide essential basic business tools, such as opening an account and other routine financial advice. After the startup succeeds in its IPO, banks get enough confidence to extend credit facilities to startups.

Finance and investment decision-making are permanently attached with its risk component. Entrepreneurs must understand the risks associated with their startup and the decision-making choices available to them. Different risk mitigation strategies are available to new startups, and entrepreneurs are known for their risk-taking tendencies. In order to mitigate risks, they must use heuristics or 'rules of thumb' as a checklist to mitigate risks, reduce uncertainty and make a decision. Mentors or incubation center faculty often share these heuristics during the early stages of business incubation programs. One common strategy is to acquire resources to mitigate risks.

Culture: Entrepreneurial ecosystems have a cultural dimension inspired by regional cultural norms and beliefs. Therefore, entrepreneurs must understand the regional entrepreneurial culture. Firstly, two ways can achieve this by joining business incubators at an early stage and joining the local entrepreneurial network. Mentors or incubation center faculty often share success stories of local startups and entrepreneurs that may not be procured in other forms like books, publications, or news.

Support Services: Another important activity needed to cross the Valley of death is to activate the support services. There are various support services needed for ecosystems; infrastructure support (e.g., buildings, roads, energy, water, telecommunications, power supplies); (b) professional support (e.g., legal, accounting, advertising, information technology); and (c) development support including busies incubators and accelerators. in the earlier stages of any innovation, the business incubator also provides infrastructure and professional support. Therefore, entrepreneurs must be able to understand the support services for similar startups. This helps to take a pivotal decision, choosing the location of a startup. Ideally, this decision must be based on the availability of infrastructure support (e.g., telecommunications, buildings, roads, energy, water, power supplies), and this 


\section{ENTREPRENEURSHIP AND SUSTAINABILITY ISSUES}

ISSN 2345-0282 (online) http://jssidoi.org/jesi/

2021 Volume 9 Number 1 (September)

http://doi.org/10.9770/jesi.2021.9.1(40)

infrastructure support must be acquired at an early stage of the startup. On the other hand, professional supports services (e.g., legal, accounting, advertising, I.T.) must be acquired using 'outsourcing' when the need arises.

Human Capital: The role of human capital, especially the role of universities and higher education institutions, is paramount in the entrepreneurial ecosystem, but none of the items are extracted for human capital validated by experts. All the items for human capital were dropped during the analysis phase due to a validity check. This has generated a new debate. Human capital, in general, plays a vital role in helping new companies get off the ground, but they might not help cross the Valley of death.

Markets: Probably, the most binding domain of the entrepreneurial ecosystem is Markets, and it includes competitors, customers, and market mechanisms. Young entrepreneurs must identify their customers and competitors correctly, and this needs a good understanding of the market, customers, and competitors, preeminent players in the market. One of the significant differences between corporate managers and entrepreneurs is their marketing skills. Typically, corporate managers rely on traditional marketing research tools to understand their customers, while entrepreneurs use unconventional or innovative methods to understand their customers' needs and wants. Similarly, entrepreneurs use their entrepreneurial networks and market intelligence to understand their competitors and major market actors as the product are new in the market, so entrepreneurs should find early adopters as customers for the proof of concept. At the same time, they need to reach reference customers and early influencers.

Innovation is the key for entrepreneurial marketing concepts and a necessity for reaching early customers. Entrepreneurs must reach their customers in innovative manners; adopt innovative distribution channels, and develop innovative promotion techniques. They are also advised to join multinational corporation's networks.

Another critical aspect of the market is the commercialization of products or ideas. Entrepreneurs must be able to understand the commercial value of the research project/product. This can only be possible after transforming the research/idea into a saleable product or prototype with the product's current and future features. This phase needs resources to establish a potential product/idea and learning methods or techniques to scale up or mass-scale production/operations for startups.

\section{Originality}

This research offers many distinctions on many counts. Firstly, most of the literature focusing on crossing the Valley of death is industry-specific and unable to generate generalizations. For example, some literature focuses on improving the curriculum and pedagogy (Barr, et al., 2009), but the study focuses on developing a single conceptual model to cross the Valley of death. Secondly, there is no significant research or conceptual model for entrepreneurial actions bridging the gap of VoD. However, this research hypothesized to make a conceptual model crossing the VoD using the entrepreneurial ecosystem. Secondly, some literature focuses on universities' role to cross the Valley of death (Etzkowitz, 2008; Son, et al., 2020). However, the role of universities in crossing the Valley of death was not validated in this research. Finally, some research supports the view that technology transfer programs can bridge the Valley of death (Takata, et al., 2020), but that might be partially true for only high-tech products or services.

\section{Limitations}

This study has certain limitations. First, this study used a smaller sample size for the validity procedure. Larger sample size may enhance the generalizability of the research. Secondly, the scope of this study is limited to exploring and presenting the entrepreneurial actions using validity procedures using only descriptive techniques and not finding the reasons behind such patterns. 


\section{ENTREPRENEURSHIP AND SUSTAINABILITY ISSUES}

ISSN 2345-0282 (online) http://jssidoi.org/jesi/ 2021 Volume 9 Number 1 (September)

http://doi.org/10.9770/jesi.2021.9.1(40)

\section{Need for Future Research}

This study provides a baseline for further research. The agenda for further research on using an entrepreneurial ecosystem to cross the Valley of death can be classified into three novel ideas. Firstly, the respondents validated only five domains of entrepreneurial ecosystems, including Policy, Financial Capital, Culture, Support Services, and Markets. The experts did not validate the sixth domain of human capital. Now the interesting question is, human capital (universities) helps new companies get off the ground, but they might not help cross the Valley of death. Why? Secondly, this research used a battery of 60 items as entrepreneurial actions, but this list is not exhaustive.

Further research is needed to generate an exhaustive list of entrepreneurial actions to cross the Valley of death; collecting the quantitative data from incubation experts and mentors, and entrepreneurship faculty may give a chance to apply advanced statistical techniques like factor analysis or cluster analysis to analyze and create the clusters of entrepreneurs based on their input data. Thirdly, this research used the entrepreneurial ecosystem as one of the means to cross the Valley of death successfully. Other approaches or techniques may also be considered. Knowing these entrepreneurial strategies would be beneficial for academicians and as well as for entrepreneurs, incubation managers, mentors, venture capitalists, and other entrepreneurial network members. All these questions require in-depth research and analysis from a brand equity point of view.

\section{References}

Abdul-Rahim, H., \& Saad, A. (2015). The shift from traditional marketing to entrepreneurial marketing practices: A literature review. Business and Management Studies, 1(2), 1-6. http://dx.doi.org/10.11114/bms.v1i2.993

Abereijo, I. O. (2015). Transversing the "valley of death": Understanding the determinants to commercialisation of research outputs in Nigeria. African Journal of Economic and Management Studies. 6(1), 90-106. https://doi.org/10.1108/AJEMS-10-2012-0066

Al Natsheh, A., Gbadegeshin, S. A., Ghafel, K., Mohammed, O., Koskela, A., Rimpiläinen, A., \& Kuoppala, A. (2021). The Causes of Valley of Death: A Literature Review. In Proceedings of INTED2021 Conference. 8(9).

http://doi.org/10.21125/inted.2021.1943

Barr, S., Baker, T., Markham, S., \& Kingon, A. (2009). Bridging the Valley of death: Lessons learned from 14 years of commercialization of technology education. Academy of Management Learning and Education, 8(3), 370-388. http://doi.org/10.5465/AMLE.2009.44287937

Barron, E., \& Amorós, J. E. (2020). Bridging the Valley of death: Lessons from an entrepreneurial program. International Journal of Entrepreneurship, 24(1) Retrieved from www.scopus.com

Belz, A., Terrile, R. J., Zapatero, F., Kawas, M., \& Giga, A. (2019). Mapping the "Valley of death": Managing selection and technology advancement in NASA's small business innovation research program. IEEE Transactions on Engineering Management,

DOI: http://doi.org/10.1109/TEM.2019.2904441

Bosma, N., \& Holvoet, T. (2015). The role of culture in entrepreneurial ecosystems: An investigation for European regions. In $6^{\text {th }}$ Annual George Washington University (GWU)-International Council for Small Business (ICSB) Global Entrepreneurship Research and Policy Conference.

Brettel, M., Engelen, A., Müller, T., \& Schilke, O. (2011). Distribution channel choice of new entrepreneurial ventures. Entrepreneurship Theory and Practice, 35(4), 683-708. http://doi.org/10.1111/j.1540-6520.2010.00387.x

Calza, F., Ferretti, M., Panetti, E., \& Parmentola, A. (2020). Moving drug discoveries beyond the Valley of death: The role of innovation ecosystems. European Journal of Innovation Management, http://doi.org/10.1108/EJIM-11-2019-0342

Cavallo, A., Ghezzi, A., Dell'Era, C., \& Pellizzoni, E. (2019). Fostering digital entrepreneurship from startup to scale-up: The role of venture capital funds and angel groups. Technological Forecasting and Social Change, 145, 24-35.

Chandra, A., \& Fealey, T. (2009). Business incubation in the United States, China and Brazil: A comparison of role of government, incubator funding and financial services. International Journal of Entrepreneurship, 13, 67.

Custodio, M. C., Demont, M., Laborte, A., \& Ynion, J. (2016). Improving food security in Asia through consumer-focused rice breeding. Global Food Security, 9, 19-28.

DaSilva, E. (1997). University-industry collaboration in Technology: a catalyst for self-reliant development. World Journal of Microbiology and Technology, 14(2), 155-161.

Dobrenkov, V. I., Afonin, Y. A., Gagarinskaya, G. P., Orlova, L. V., Pronina, N. N., \& Sabirova, G. T. (2017). Innovative development: International experience of intellectual property commercialization, 20(4A), 241-252. http://doi.org/10.35808/ersj/831 


\section{ENTREPRENEURSHIP AND SUSTAINABILITY ISSUES}

ISSN 2345-0282 (online) http://jssidoi.org/jesi/ 2021 Volume 9 Number 1 (September) http://doi.org/10.9770/jesi.2021.9.1(40)

Donaldson, C. (2021) Culture in the entrepreneurial ecosystem: a conceptual framing. International Entrepreneurship Management Journal, 17, 289-319. https://doi.org/10.1007/s11365-020-00692-9

Duan, C., Sandhu, K. \& Kotey, B. (2021). Understanding immigrant entrepreneurship: a home-country entrepreneurial ecosystem perspective. New England Journal of Entrepreneurship, 24(1), 2-20. https://doi.org/10.1108/NEJE-05-2020-0013

Dubina, I. N., \& Ramos, S. J. (2016). Cultural Underpinnings in Entrepreneurship. In I. N. Dubina, \& E. G. Carayannis, Creativity, Innovation, and Entrepreneurship Across Cultures: Theory and Practices (pp. 147-153). New York: Springer. https://doi.org/10.1007/978-1-4939-3261-0_12

Dye, C. W., \& Barbe, D. F. (2015). A Lab-to-Market Ecosystem in an Academic Environment. In Competitive Strategies for Academic Entrepreneurship: Commercialization of Research-Based Products (pp. 123-142). IGI Global.

Etzkowitz, H. (2008). The Triple Helix: University-Industry-Government Innovation in Action; Routledge: New York, NY, USA; London, UK, 2008; p. 164.

Etzkowitz, H., Mack, A., Schaffer, T., Scopa, J., Guo, L., \& Pospelova, T. (2020). Innovation by design: SPARK and the overcoming of Stanford university's translational "Valley of death" in bio-medicine. Managerial and Decision Economics, 41(6), 1113-1125. https://doi.org/10.1002/mde.2966

European Patent Office (2020) https://www.epo.org/news-events/in-focus/Technology-patents.html

Falahat, M., Ramayah, T., Soto-Acosta, P., \& Lee, Y. Y. (2020). SMEs internationalization: The role of product innovation, market intelligence, pricing and marketing communication capabilities as drivers of SMEs' international performance. Technological Forecasting and Social Change, 152, 119908.

Frost, F. A. (2015). New Product Development-Technology in Australia. In Global Perspectives in Marketing for the 21 st Century (pp. 287-296). Springer, Cham.

Gejun, Huang (2021) Social capital and financial capital acquisition: creating gaming ventures in Shanghai's entrepreneurial ecosystem, Chinese Journal of Communication, 14(1), 5-23. http://doi.org/10.1080/17544750.2020.1762686

Goldfarb, B., \& Henrekson, M. (2003). Bottom-up versus top-down policies towards the commercialization of university intellectual property. Research policy, 32(4), 639-658.

Gunasekara, C. (2006). Reframing the role of universities in the development of regional innovation systems. The Journal of Technology Transfer, 31(1), 101-113.

Hallen, B. L., Davis, J. P., \& Murray, A. (2020). Entrepreneurial network evolution: Explicating the structural localism and agentic network change distinction. Academy of Management Annals, 14(2), 1067-1102.

Halt, G. B., Donch, J. C., Stiles, A. R., \& Fesnak, R. (2017). Intellectual property and financing strategies for technology startups. Springer.

Hausberg, J. P., \& Korreck, S. (2021). Business incubators and accelerators: a co-citation analysis-based, systematic literature review. Handbook of Research on Business and Technology Incubation and Acceleration.

Hermanto, B. (2017). Entrepreneurship ecosystem policy in Indonesia. Mediterranean Journal of Social Sciences, 8(1), 110-110. DOI: http://doi.org/10.36941/mjss

Hofstede, G. H., Hofstede, G. J., \& Minkov, M. (2010). Cultures and organizations: software of the mind. McGraw-Hill.

Isenberg, D. (2011). The entrepreneurship ecosystem strategy as a new paradigm for economy policy: principles for cultivating entrepreneurship. Babson entrepreneurship ecosystem project, Babson college, Babson Park: M.A.

Islam, N. (2017). Crossing the Valley of death-An integrated framework and a value chain for emerging technologies. IEEE Transactions on Engineering Management, 64(3), 389-399. https://doi.org/10.1109/TEM.2017.2685138

Jucevičius, G., Jucevičienè, R., Gaidelys, V., \& Kalman, A. (2016). The emerging innovation ecosystems and" Valley of death": towards the combination of entrepreneurial and institutional approaches. Inžinerine ekonomika, 27(4), 430-438.

Jackson, W. T., Scott, D. J., \& Schwagler, N. (2015). Using the business model canvas as a methods approach to teaching entrepreneurial finance. Journal of Entrepreneurship Education, 18(2), 99. http://dx.doi.org/10.5539/ass.v12n10p55

Jauhiainen, J. S. (2021). Entrepreneurship and Innovation Events during the COVID-19 Pandemic: The User Preferences of VirBELA Virtual 3D Platform at the SHIFT Event Organized in Finland. Sustainability, 13(7), 3802. https://doi.org/10.3390/su13073802

Johannisson, B. (1991). University training for entrepreneurship: Swedish approaches. Entrepreneurship \& Regional Development, 3(1), 67-82. https://doi.org/10.1080/08985629100000005

Johannisson, B., Landstrom, H., \& Rosenberg, J. (1998). University training for entrepreneurship - an action frame of reference. European Journal of Engineering Education, 23(4), 477-496. https://doi.org/10.1080/03043799808923526

Lissoni, F. (2012). Academic patenting in Europe: An overview of recent research and new perspectives. World patent information, 34(3), 197-205.

Lynn, L. H., \& Kishida, R. (2004). Changing paradigms for Japanese technology policy: SMEs, universities, and Technology. Asian Business \& Management, 3(4), 459-478.

Markham, S. K. (2002). Moving technologies from lab to market. Research-Technology Management, 45(6), 31-42. https://doi.org/10.1080/08956308.2002.11671531

Markham, S. K. (2002). Moving technologies from lab to market. Research-Technology Management, 45(6), 31-42.

Mcintyre, R. A. (2014). Overcoming The Valley of Death. Science progress, 97(3), 234-248. http://doi.org/10.3184/003685014X14079421402720

McMullan, W., \& Melnyk, K. (1988). University innovation centres and academic venture formation 1. R\&D Management, $18(1), 5-12$.

Merrifield, B.D. (1995). Obsolescence of Core Competencies versus Corporate Renewal. Technology Management, 2(2), 73-83. 


\section{ENTREPRENEURSHIP AND SUSTAINABILITY ISSUES}

ISSN 2345-0282 (online) http://jssidoi.org/jesi/ 2021 Volume 9 Number 1 (September) http://doi.org/10.9770/jesi.2021.9.1(40)

Minniti, M. (2008). The role of government policy on entrepreneurial activity: productive, unproductive, or destructive. Entrepreneurship Theory and Practice, 32(5), 779-790.

Mufamadi, M. S. (2019). From lab to market: Strategies to commercialization in Africa. MRS Bulletin, 44(6), 421-422.

Nieto Cubero, J., Consolación Segura, C. M., \& Adebayo Gbadegeshin, S. (2020). Commercialization process of disruptive innovations in corporate ventures and spin-off companies: a comparison. Advances in Science, Technology and Engineering Systems Journal, 5(2), 621-634. https://doi.org/10.25046/aj050278

Owen-Smith, J., \& Powell, W. W. (2003). The expanding role of university patenting in the life sciences: assessing the importance of experience and connectivity. Research Policy, 32(9), 1695-1711. https://www.uspto.gov/patents-getting-started/generalinformation-concerning-patents

Pauwels, C., Clarysse, B., Wright, M., \& Van Hove, J. (2016). Understanding a new generation incubation model: The accelerator. Technovation, 50, 13-24.

Prasetyo, P. E. (2020). Human capital as the main determinant of regional economic growth. International Journal of Advanced Science and Technology, 29(03), 6261-6267.

Putta, S. S. (2014). Improving entrepreneur's management skills through entrepreneurship training. Journal of Commerce and Management Thought, 5(3), 459-474. https://doi.org/10.5958/0976-478X.2014.00334.6

Qureshi, M. S., Saeed, S., \& Wasti, S. W. M. (2016). The impact of various entrepreneurial interventions during the business plan competition on the entrepreneur identity aspirations of participants. Journal of Global Entrepreneurship Research, 6(1), 1-18. DOI: https://doi.org/10.1186/s40497-016-0052-0

Roles of U.S. Regulatory Agencies (2020) https://www.usda.gov/topics/Technology/how-federal-government-regulates- -plants

Salgado, E. G., Sanches da Silva, C. E., Mello, C. H. P., \& Samaan, M. (2017). Critical success factors for new product development in Technology companies. Engineering Management Journal, 29(3), 140-153.

Schön, D. A.(1963) Champions for Radical New Inventions. Harvard Business Review, 41(2).

Shinkle, G. A., \& Suchard, J. A. (2019). Innovation in newly public firms: The influence of government grants, venture capital, and private equity. Australian Journal of Management, 44(2), 248-281.

Siddiqui, K. A., Siddiqui, A., \& Alaraifi, A. (2018). Managing University Business Incubators in Saudi Arabia. In ICIE $20186^{\text {th }}$ International Conference on Innovation and Entrepreneurship: ICIE 2018 (p. 418). Academic Conferences and publishing limited. https://www.proquest.com/openview/5424ee97aaaf63e2bce5ab847666747d/1.pdf?cbl=4451211\&pq-origsite=gscholar

Son, H., Chung, Y., \& Yoon, S. (2020). How can university technology holding companies bridge the Valley of Death? Evidence from Korea. Technovation, 102158. https://doi.org/10.1016/j.technovation.2020.102158

Stam, E., van de Ven, (2021). A. Entrepreneurial ecosystem elements. Small Bus Econ, 56, 809-832. https://doi.org/10.1007/s11187-01900270-6

Savaneviciene, A., Venckuviene, V., \& Girdauskiene, L. (2015). Venture capital a catalyst for startups to overcome the "Valley of death": Lithuanian case. Procedia Economics and Finance, 26, 1052-1059.

Stefanelli, V., Boscia, V., \& Toma, P. (2020). Does knowledge translation drive spin-offs away from the "valley of death". A nonparametric analysis to support a banking perspective. Management Decision, 58(9), 1985-2009. http://doi.org/10.1108/MD$\underline{11-2019-1579}$

Sun, S. L., Zhang, Y., Cao, Y., Dong, J., \& Cantwell, J. (2019). Enriching innovation ecosystems: The role of government in a university science park. Global Transitions, 1, 104-119.

Sung, D. (2021). Notes from the Valley of death: A case for entrepreneurship in architecture. Technology Architecture and Design, 5(1), 20-24. http://doi.org/10.1080/24751448.2021.1863662

Taatila, V.P. (2010). Learning entrepreneurship in higher education. Education + Training, 52(1), 48-61. https://doi.org/10.1108/00400911011017672

Takata, M., Nakagawa, K., Yoshida, M., Matsuyuki, T., Matsuhashi, T., Kato, K., \& Stevens, A. J. (2020). Nurturing entrepreneurs: How do technology transfer professionals bridge the Valley of death in Japan. Technovation, http://doi.org/10.1016/j.technovation.2020.102161

Türko, E. S. (2016). Business plan vs business model canvas in entrepreneurship trainings, a comparison of students' perceptions. Asian Social Science, 12(10), 55-62. 10.5539/ass.v12n10p55

Upadhyayula, V. K., Gadhamshetty, V., Shanmugam, K., Souihi, N., \& Tysklind, M. (2018). Advancing game changing academic rese arch concepts to commercialization: A Life Cycle Assessment (LCA) based sustainability framework for making informed decisions in Technology Valley of Death (TVD). Resources, Conservation and Recycling, 133, 404-416. https://doi.org/10.1016/j.resconrec.2017.12.029

Verhoeff, A., \& Menzel, H. (2011). Social capital to bridge the Valley of death, simulating critical incidents in innovation. International Journal of Entrepreneurship and Small Business, 14(1), 149-169. http://doi.org/10.1504/IJESB.2011.042167

Williams, C., \& Lee, S. H. (2009). Resource allocations, knowledge network characteristics and entrepreneurial orientation of multinational corporations. Research Policy, 38(8), 1376-1387. http://dx.doi.org/10.1016/j.respol.2009.05.007

Zaech, S., \& Baldegger, U. (2017). Leadership in startups. International Small Business Journal, 35(2), 157-177. 
Dr. Mohammed Emad AL-SHAIKH is an Assistant Professor of Entrepreneurship at College of Business Administration, Imam Abdulrahman Bin Faisal University, Saudi Arabia. He is also head of the IAU entrepreneurship unit and business incubator. Research interests: business, entrepreneurship, entrepreneurial marketing, business incubators and accelerators.

ORCID ID: 0000-0003-4545-3938

Dr. Kamran SIDDIQUI is an Associate Professor of Marketing and Entrepreneurship at the College of Business Administration, Imam Abdulrahman Bin Faisal University, Saudi Arabia. Research interests: entrepreneurship, business incubators and accelerators, entrepreneurial marketing, venture capital.

ORCID ID: 0000-0002-5724-0991

Make your research more visible, join the Twitter account of ENTREPRENEURSHIP AND SUSTAINABILITY ISSUES: @Entrepr69728810

Copyright (C) 2021 by author(s) and VsI Entrepreneurship and Sustainability Center

This work is licensed under the Creative Commons Attribution International License (CC BY).

http://creativecommons.org/licenses/by/4.0/

cC) (i) Open Access 